8. Майдан I.С. Психоемоційні порушення у жінок як предиктор розвитку непліддя. Слово о здоровье. 2017. 12. 41-44.

9. Щорічна доповідь про стан здоров'я населення, санітарноепідемічну ситуацію та результати діяльності системи охорони здоров'я України. 2015 рік / за ред. В. В. Шафранського; МОЗ України; ДУ «УІСД МОЗ України». - К.. 2016. 452.

10. Michael A.E., Papageorghiou A.T. Potential significance of physiological and pharmacological glucocorticoids in early pregnancy. Human Reproduction Update. 2008.14 (5). 497-517.

DOI https://doi.org/10.30525/978-9934-588-81-5-1.12

\title{
PRESEPSIN IS A DIAGNOSTIC MARKER OF THE SEVERITY OF SEPSIS
}

\author{
Voloboyeva A. $O$. \\ Department of Anesthesiology \\ Communal Municipal Clinical Hospital № 8 \\ Lviv, Ukraine \\ Fuss Yu. O. \\ Department of Surgery \\ Regional Hospital in Pustomyty \\ Pustomyty, Lviv region, Ukraine
}

Introduction. Sepsis is a complex and urgent problem of modern medicine around the world $[1,2]$. Early diagnosis of sepsis allows you to diagnose in time, assess the patient's condition, begin treatment. Biomarkers are important in the early diagnosis of sepsis, indicating the presence or absence of this infectious complication [3, 4]. Presepsin (PSP) is a new biomarker of bacterial and fungal systemic infections [5].

Material and methods. 96 patients were studied. The mean age of patients was $63.2 \pm 2.35$ years. All patients were treated in PCRL and $8 \mathrm{MCL}$ from 2018-2019. Patients were divided into two groups: I - 51 (53\%) patients with abdominal sepsis, II - 45 (47\%) patients with other inflammatory diseases (appendicitis, cholecystitis, etc.). The level of PSP was quantified on an immunochemiluminescent analyzer Pathfast (Mitsubishi Chemical Medience Corporation, Japan). All patients received antibiotic therapy. 
Results. The level of PSP in abdominal sepsis was $3,122.8 \pm 476.2 \mathrm{pg} / \mathrm{ml}$, in other diseases $-933.00 \pm 94.87$. The level of PSP in abdominal sepsis was $1537.89 \pm 325.4 \mathrm{pg} / \mathrm{ml}$ - lower compared with patients with severe sepsis $4985.60 \pm 839.85 \mathrm{pg} / \mathrm{ml}(\mathrm{p}<0.05)$.

Conclusion.

1. High level of presepsin - an indicator of active infectious pathology. At pneumogenic sepsis in the general group the indicator of PSP made $3122,8 \pm 476,2 \mathrm{pg} / \mathrm{ml}$, at abdominal sepsis $-2946,2 \pm 497,32 \mathrm{pg} / \mathrm{ml}$, at other inflammatory diseases $-933,00 \pm 94,87 \mathrm{pg} / \mathrm{ml}$;

2. The higher the level of presepsin, the more severe the sepsis

3. PSP - a reliable marker of diagnosis, determination of the severity of sepsis and the effectiveness of therapy.

\section{References:}

1. Behnes M., Bertsch T., Lepiorz D. et al. Diagnostic and prognostic utility of CD 14 subtype (presepsin) for severe sepsis and septic shock during the first week of intensive care treatment. Crit. Care. 2014, 18 (5): 507.

2. Shozushima T., Takahashi G., Matsumoto N. et al.Usefulness of presepsin (sCD 14_ST) measurements as a marker for the diagnosis and severity of sepsis that satisfied diagnostic criteria of systemic inflammatory response syndrome. J. Infect. Chemother. 2011; 17 (6): 764-769.

3. Saito J., Hashiba E., Kushikata T. et al. Changes in presepsin concentrations in surgical patients with end_stage kidney disease undergoing living kidney transplantation: a pilot study. J. Anesth. 2016; 30 (1): 174-177.

4. Zhang J., Hu Z., Song J. et al. Diagnostic value of presepsin for sepsis. Medicine. 2015; 94 (47): e2158:64-68.

5. Liu B., Yin Q., Chen Y.X. et al. Role of Presepsin (sCD14_ST) and the CURB65 scoring system in predicting severity and outcome of community_acquired pneumonia in an emergency department. Respir. Med. 2014; 108 (8): 1204-1213. 